\title{
The Interdisciplinary Integration of the Mathematical and Economic Disciplines within the Modern Economic Education
}

\section{Shelekhova Lyudmila Valeryevna}

Federal State Budget Institution of Higher Professional Education «Adyghe State University» (ASU), 385000, Maikop, street Pervomayskaya, 208, Russian Federation; Email: nisadgu@yandex.ru

\author{
Doi:10.5901/mjss.2015.v6n5s1p122
}

\section{Abstract}

\begin{abstract}
The article describes the features and conditions of the successful interdisciplinary integration of the mathematical and economic disciplines within the educational practices of higher education institutions, emphasizes the importance and significance of the mathematic education for the future professional activities. It states that the most important factors contributing to the effective implementation of the mathematical and economic disciplines include: the coordination of the timespace characteristics of the process of studying various academic disciplines and all components of the educational space; the consideration of the prior conceptual framework and the natural interrelation of educational material on the mathematical and economic disciplines based on their interdependence and complementarity; the implementation of a unified approach to the educational process; the adherence to the succession and continuity in the development of the concepts providing for the enrichment with the new content and communications; the unity in interpretation of the general scientific notions; the avoidance of duplicating the same concepts while studying different subjects; the commitment not only to the fundamental nature of mathematical training, but also to the implementation of the professional functions of mathematics; the determination of the core areas of mathematics courses, their basic ideas, generalizations, leading concepts, categories, and their natural integration with the economic theories (the principle of generalization of knowledge in the direction from the main (common) properties of knowledge to the specific (individual) knowledge and vice versa). It substantiates the author's point of view on the interdisciplinary integration as a single educational space based on the interdependence and complementarity of the content of mathematical and economic disciplines, in order to implement the system of generalized professional knowledge and master the skills and abilities to apply effectively the knowledge in the future professional activities.
\end{abstract}

Keywords: interdisciplinary integration, content of the higher professional education, mathematics education, professional mobility.

\section{Introduction}

In the course of obtaining higher education, students are not able to master all the knowledge that may be needed in their profession. Since the modern economic space is characterized by the rapid professional reorientation within the constantly changing environment (the changes occur in the product range, technological processes, approaches to the production management, etc.), the higher education must be focused on the formation of qualities that will enable the future specialists to feel confident within the labor market.

A competitive specialist in the field of economy who is focused on the sphere of professional activity must be less rigidly tied to a specific object and subject of labor. That is impossible without a high level of generalization of the knowledge obtained in the course of professional training, without the skill to select and implement the optimal methods intended to perform tasks not only in one's own, but also in the allied professions. According to Einstein, poor understanding of the importance of awareness of the scientific knowledge unity can lead to a decrease in the "true depth of the research spirit," i.e. to the superficial perception of the issues studied, which "threatens to take away from a researcher the broad prospects levelling him down to a craftsman" (Einstein, 1965). As a result of the isolated study of the general professional, mathematical, and special disciplines, the students fail to obtain proper knowledge and skills that if applied properly would help solve practical problems related to the future profession, since "each discipline focuses only on one of the sides of the reality considered" (Newell, 2001). As a result thereof, the students of economics are usually not conscious of the need to study individual disciplines, particularly the mathematical ones. The solution of this problem is to overcome the contradiction between the necessity of mastering the professionally-oriented mathematical activities by the future economists and the established system of mathematics education within the institutions of higher education that do not consider the interdisciplinary integration as one of the productive directions of the professional training of the students of economics (Shelekhova, 2014). 
Improvement of the mathematical training of the future economists with account of the professionally oriented activities assumes the orientation of mathematical material not so much on the acquisition of knowledge on this subject, as on the interdisciplinary approach and the integrated nature of training, the basics of which are disclosed in the psychological and pedagogical studies of comprehensive training that was further developed in the last century. However, the means of comprehensive training failed to solve the following problems: 1) the building of formal communications between the academic disciplines without regard to their content-related uniqueness; 2) the establishment of equal conditions for studying the content-related aspect of the fundamental sciences at structuring the "universal" training material, which resulted in acquisition of superficial knowledge in individual academic disciplines, in particular in mathematics (Shestakova, 2013). Furthermore, currently the issue under consideration is characterized by the existing synonymy (simultaneous implementation of a series of terms) within the pedagogical terminology: "intersubjectness," "interdisciplinarity," "intersubject integration," "interdisciplinary integration," "interdisciplinary," "cross-disciplinary," and "trans-disciplinary."

While considering the concept of "integration" (from the Latin, "integration"-an update, replenishment, "inteqer" integral) as the assembly of parts and elements into the whole within the theory and practice of training at higher education institutions, the interdisciplinary integration (integration of academic disciplines, integrated courses, integrated lessons) is represented in the following form:

1) the ability to integrate knowledge and considerations in two or more disciplines or established spheres of the experience in producing cognitive development (Boix-Mansilla and Duraising, 2007);

2) the establishment of a unified educational space demonstrating a holistic development potential through the implementation of the innovative pedagogical and didactic methods, organizational forms of training, and the formation of competences, the interpenetration of content of various academic disciplines (Shestakova, 2013; Chebyshev and Kagan, 2000).

Both approaches reflect different sides of the same phenomenon that drastically alters the content and structure of the modern scientific knowledge, the intellectual and conceptual possibilities of individual academic disciplines. Which, according to Strizhkova, is the most important means of achieving the unity of knowledge in the content-related, structural, logical-gnoseological, scientific-organizational, general didactic, private-methodological, and pedagogical aspects (Strizhkova, 2000).

\section{Methodology}

When considering the conditions of implementation of the interdisciplinary integration of academic disciplines in the educational process, we analyzed first the pedagogical conditions that should reflect the content, methods, competences, ways of thinking, and characteristic forms of an object (Bechmann, 2009). That is consistent with the identified by Bruner (1977) lines of research of the process of learning with a view to its improvement, which suggests as follows:

a) distinguishing the leading, core concepts within the content of each discipline in order to make it more comprehensible for a student;

b) implementing the particular factors together with the cognitive structures and patterns during the course of presenting the material;

c) seizing the means of cognitive activity, which are significant and beyond the content of a particular academic discipline;

d) expediently applying the "spiral-type" study of the basic ideas and concepts.

All of the above mentioned is aimed at raising the level of awareness of the studied educational material, which manifests itself in the use of information taken from the subject studied, from one or more disciplines that are close to the subject studied, the broad interdisciplinary communications from various disciplines for reasoning the set out provisions (Bespal'k, 1989). That is the highest level of awareness is manifested in the formation of scientific concepts on an interdisciplinary basis, which according to Chebyshev and Kagan (1998) implies the presence of pedagogical, general didactic, and psychological conditions:

1) the consistent in time study of individual academic disciplines, in which each of them is based on the preceding conceptual framework and prepares students for the successful mastering of concepts of the subsequent discipline;

2) the necessity of ensuring the succession and continuity in the development of concepts; from a discipline to a discipline, the concepts being common for a series of disciplines must constantly develop, acquire new content, and be enriched with the new communications;

3) the unity in interpretation of the general scientific notions; 
4) the avoidance of duplicating the same concepts while studying different subjects;

5) the implementation of a common approach to the disclosure of the similar classes of concepts.

Based on the previously mentioned, it is primarily required to supplement the mathematics material with the material of economic disciplines combining the selected parts to form a whole. Considering the possibilities of organizing the intercommunications between the major disciplines, Verbitskii notes that the "content of the inclusion can be obtained in case when the content of one academic subject is assimilated together with the content of another one. This is a kind of the resource saving technology: for the same time and under the same conditions, not one but two goals are achieved" (Verbitskii, 1991). Within the conditions of the academic time shortage, this will allow to eliminate the consideration of the same issues in various disciplines (Bekrenev, 1996). That is, the integration of the content of academic disciplines is positioned as the resource saving technology that allows to intensify the process of learning at increasing its efficiency, which can be implemented through the identification of relations between the various disciplines; the establishment of the high quality assessment of the content-related aspect of disciplines; the determination of the succession and continuity when studying disciplines; the avoidance of duplicating the same material in different disciplines.

The specified directions are quite complicated in the process of practical implementation of the basic mathematical disciplines (linear algebra, analytic geometry, mathematical analysis, and theories of probability and mathematical statistics), since according to the logical sequence of disciplines in the educational process, they are studied prior to the economic disciplines. Probably, this can explain the results of the conducted analysis described in the courseware on the interdisciplinary communications of the mathematical and economic disciplines, which showed that the holistic integrative courses did not exist. Moreover, in contrast to the mathematical analysis and probability theory, only some of the topics of linear algebra are illustrated by the applied problems, and analytic geometry is completely reduced to the study of the basic mathematical knowledge only. On the one hand, we agree with those who state that "the majority of the most important concepts in economics, such as budget lines, supply and demand, price equation, flexibility, marginal utility, etc., in fact, are the specific examples of the standard concepts of mathematical analysis, such as derivative, logarithmic derivative, function, etc." (Kolesnikov, 2001). On the other hand, one should not underestimate the role of the course of linear algebra and analytic geometry within the economic theory, since each of the branches of mathematics explores only one aspect of the economic phenomena under consideration. And if at least one of the branches is not represented, then such a research is unilateral and carries the danger of losing the whole. All the more so as in this course of mathematics, it is possible to use the simplest examples illustrating the application of mathematical concepts for the study of real phenomena that are sufficiently presented in the economic science: budget set, price index, amount of dividends, the expected value of yield, etc. At the same time, at any combination of materials, the idea of the studied topic on mathematics, to which the class is devoted, must remain the leading, the basic one.

The integrative intercommunications of the mathematical and economic disciplines can be carried out in three levels:

1) the level of integrity comprising the content-related and procedural integration within the framework of the new subject;

2) the level of didactic synthesis comprising the integration of academic subjects on the basis of one of them. At the same time, each of the subjects retains its status;

3) the level of interdisciplinary communications that determines the common elements of the educational content as the integration factor (Berulava, 1988).

Within the framework of the modern education standards of the higher education institutions, the most probable is the third level. According to Semushina and laroshenko, the intersubject communications represent the "objectively existing communications between the information from the different fields of science and practice included into the content of education" (Semushina and laroshenko, 1990). At the absence of the intersubject communications, the "system of students' knowledge has the intersubject gaps or duplications, and represents a conglomerate of the slightly interconnected information that the students do not know how to put into practice" (Kustov, 1985). At the same time, the modern subject-related system of learning in the higher education institutions, as a rule, is aimed at the narrowly specialized knowledge, which does not interact with its branches and with the reality. In order to change this, it is necessary in the course of lectures, seminars, and individual work of the students to use:

1) the knowledge of other subjects, practices, life experience of students, the previously acquired knowledge in a new situation, examples from other disciplines, during the study of the new knowledge;

2) the method for implementation of the intersubject communications based on the generality of laws, theories, principles, and basic provisions that enables the use of the theories, laws, and principles of one subject to explain the phenomena and processes in the other disciplines;

3) the unity of the interpretations of concepts, phenomena, and processes involving the refinement and the 
distinction between the concepts of similar meanings; the disclosure of communications between the phenomena and processes studied in various fields of knowledge;

4) the interdisciplinary projects, tasks, and professionally oriented problems. A special role is given to the project method that is aimed at achieving a didactic objective through the solution of a problem that is arranged as a real, practical result, which suggests its presentation. The pedagogical value of the projects of intersubject nature is that they:

a) involve comprehensive application of the knowledge acquired during the study of various disciplines;

b) stimulate the cognitive activity of a student;

c) provide an opportunity for the subjects of academic training to take not just simply an active, but also a proactive position in the training process, not just to assimilate the proposed educational material of the mathematical and economic disciplines, but also to search personally for the answers to the raised educational and professional questions;

d) allow on the basis of the gradual sophistication of the types of orientation (from the demonstration of problems with the economic content to the scientific and research work of students in the training process, from the simulated professional situations to the application of the acquired knowledge in practice) to integrate the content and methodological aspects of the higher mathematics course for economic specialties, which contributes to:

- the comprehensive analysis of the content of educational material on mathematics and economics from different perspectives;

- the more profound assimilation of knowledge, as the knowledge acquires the qualities of systematicity;

- the improvement of the professional education quality, since the acquired knowledge is richer in its content and broader in its scope, than the knowledge of each individual discipline involved in its acquisition;

- the establishment of favorable conditions for deeper understanding and creative processing of the studied material on the mathematic and economic disciplines, as the abilities become generalized and holistic;

- the enhancement of the worldview orientation of the cognitive interests of students, since the learning material reflects the studied object in other aspects and characteristics;

- the creative reconsideration of the traditional procedures and forms of the academic affairs.

All these are the important factors in the formation of self-sufficiency of the student's search activities, and his manifestation as a subject of training.

Despite the evidence of a positive impact of the interdisciplinary integration imposed on the quality of the educational process, it is necessary to distinguish the complexity of its application, while, firstly, it requires the clear determination of the components and structure of knowledge on each discipline being a part of the integrated course. Only at presence of the central idea between the disciplines, it becomes possible to disclose the interpenetration of two disciplines, the establishment of the content-related conformity of training programs on each course (Bekh, 2002). Secondly, the implementation of the interdisciplinary integration in the conditions of a credit-modular system faces certain difficulties because the volume of knowledge, abilities, and skills (from the largest to the smallest one) is clearly regulated with respect to each module, and the interdisciplinary integration primarily assumes the establishment of the developing environment by means of the project-based training.

Within the system of the higher economic education, the mathematical disciplines are considered as an integral part of the professional training. Therefore, Aleksandrov pointed out that "currently, due to the increased role of mathematics in the contemporary science and engineering, a great number of the future engineers, economists, sociologists, etc. feel the need for serious mathematical training, which could provide a possibility for investigating a wide range of the new challenges through the mathematical methods, and applying the theoretical achievements in practice" (Aleksandrov, 1980). For today, we have managed to solve this problem partially for the mathematical disciplines that consider the mathematical methods in economics (mathematical economics, mathematical modeling of economics, and economic-mathematical methods). However, within the frameworks of just the mathematical disciplines, it is impossible to solve all the problems of the integration processes that currently occur, and will occur in the nearest future with respect to the mathematics education in the higher education institutions as a result of the new requirements. Therefore, it is required at the stage of formation of the curriculum, work programs, and logframes to consider the content of the academic disciplines of all departments (Jankvist, 2011; Golding, 2009). That is, the students' confidence in the 
usefulness and necessity of the mathematical knowledge can be established only if it will be implemented widely enough when teaching special disciplines during the entire training. Moreover, the systematic application of the mathematical methods, studied by students within the course of mathematics, to the solution of the applied economic problems must be necessarily implemented at the major departments. If that does not happen, then on the one hand, it indicates on that the economic courses are disclosed without considering the requirements of the federal national standard, and on the other hand, it indicates on that the teachers of special economic disciplines are personally not sufficiently proficient in mastering the existing mathematical apparatus.

\section{Results}

With this approach, as it has been shown by the analysis of the psychological and educational literature and by our research, the interdisciplinary integration imposes mandatory requirements, by which each of the mathematical and economic disciplines (any changes in the requirements should be methodologically substantiated):

1) is coordinated with regard to:

- the time-based spatial characteristics within the process of studying various academic disciplines;

- all components of the educational space (sections, internal and intersubject communications between the topics of the mathematical and economic disciplines, etc.) that are integrated based on the content of each discipline;

2) is based on:

- the preceding conceptual framework;

- the implementation of a unified approach to the arrangement of the educational process;

- the natural interrelation of the educational material on the mathematical and economic disciplines based on their interdependence and complementarity.

3) abides by:

- the succession and continuity in the development of concepts providing for the enrichment with the new content and communications;

- the unity in interpretation of the general scientific concepts;

_ the avoidance of duplicating the same concepts while studying different subjects.

4) refers to:

- not only to the fundamental nature of mathematical training, but also to the implementation of the professional functions of mathematics;

- $\quad$ to the determination of the core areas of mathematics courses, their basic ideas, generalizations, leading concepts, categories, and their natural integration with the economic theories (the principle of generalization of knowledge in the direction from the main (common) properties of knowledge to the specific (individual) knowledge and vice versa).

As Shestakova mentioned in her definition, the compliance with the above-mentioned requirements is possible only in the event of establishing a "unified educational space" (Shestakova, 2013). This space can be considered as a generic term for the concept of "interdisciplinary integration". However, the possession of a holistic potential for the "development through the implementation of the innovative pedagogical and didactic methods, organizational forms of training, and the formation of competences" cannot be considered as a generic difference since this characteristic is a requirement of the modern higher education regardless of whether it is an interdisciplinary one or not. Therefore, in agreement with BoixMansilla, we will consider the interdependence and complementarity of the content of various disciplines as a generic difference (Boix-Mansilla, 2007). They contribute not only and not so much to the cognitive development of students (since this development is possible at any type of training), as it is more focused on the assimilation by the system of the generalized professional knowledge and on the mastering of the skills and abilities to effectively apply them in one's future professional activities. All of the above mentioned has allowed us to consider the interdisciplinary integration as a unified educational space based on the interdependence and complementarity of the content of the mathematical and economic disciplines with the purpose of assimilating the system of the generalized professional knowledge and mastering the skills and abilities to effectively apply them in one's future professional activities.

\section{Summary}

While disclosing the theoretical prerequisites for optimizing the process and content of education through the integration of the mathematical and economic disciplines, we should note that it is the interdisciplinary communications that solve the contradiction existing within the subject system of education between the disjointed acquisition of knowledge and the 
necessity for its synthesis, integrated application in practice, in labor activity, and in the life of a person. Since the high quality training of specialists in economics, which allows them to perform their official duties, involves the assimilation of all the disciplines provided by the national education standard, including the one on mathematics, the role of such training consists not only in the establishment of a "foundation" for the further mastering of the general economic disciplines, but also in the formation in the future specialists of such professional skills as the ability to build models of the economic processes, and to optimize the decision-making process.

\section{References}

Aleksandrov, P.S. (1980). Vvedenie v teoriiu grupp [Introduction to the Theory of Groups] (pp. 144). Moscow: Nauka [in Russian]. Beckmann, A. (2009). A Conceptual Framework for Cross-Curricular Teaching. The Montana Mathematics Enthusiast, V. (6), Supplement 1.

Bekh, I.D. (2002). Integracija jak osvitnja perspektyva [Integration as a Prospect of Education]. Pochatkova Shkola - Primary School, 5 , 5-6 [in Ukrainian].

Bekrenev, A. (1996). Mnogostupenchatye struktury integrirovannykh sistem obrazovaniia [The Multistage Structures of the Integrated Systems of Education]. Vysshee obrazovanie $v$ Rossii - The Higher Education in Russia, 3, 37-50 [in Russian].

Bespal'ko, V.P., \& Tatur, Iu.G. (1989). Sistemno-metodicheskoe obespechenie uchebno-vospitatel'nogo protsessa podgotovki spetsialistov [The Systemic and Methodological Support of the Education and Bringing-up Process of Specialists Training] (pp. 144). Moscow: Vysshaia Shkola [in Russian].

Berulava, M.N. (1988). Integratsiia soderzhaniia obshchego i professional'nogo obrazovaniia v proftekhuchilishchakh [The Integration of the Content of General and Professional Education in the Vocational Training Schools] (pp. 221). Teoreticheskii $i$ metodologicheskii aspekt - The Theoretical and Methodological Aspect. Tomsk: Tomsk University [in Russian].

Boix-Mansilla (2007). Targeted Assessment of Students' Interdisciplinary Work: An Empirically Grounded Framework Proposal. Journal of Higher Education, 78(2), 219.

Bouillier-Oudot, Marie-Hélène. (2010). The Choice of Interdisciplinarity in French Agricultural Education. Issues in Integrative Studies, 28, 208-237.

Bruner, J. (1977). Psikhologiia poznaniia: Za predelami neposredstvennoi informatsii [Psychology of Cognition: Beyond the Direct Information] (pp. 412). Moscow: Progress [in Russian].

Golding, C. (2009). Integrating the Disciplines: Successful Interdisciplinary Subject (pp. 7). The University of Melbourne.

Jankvist U. (2011). The Construct of Anchoring- an Idea for 'Measuring' Interdisciplinarity in Teaching. Philosophy of Mathematics Education Journal, 26.

Kolesnikov, A.N. (2001). Kratkii kurs matematiki dlia ekonomistov: uchebnoe posobie [The Brief Course in Mathematics for Economists: Textbook] (pp. 2). Moscow: INFRA-M [in Russian].

Kustov, Iu.A. (1985). Preemstvennost' professional'noi podgotovki i proizvoditel'nost' truda molodezhi [The Continuity of Professional Training and Labor Performance of the Youth] (pp. 134). Saratov: Saratov University [in Russian].

Newell, W.H. (2001). A Theory of Interdisciplinary Studies. Issues in Integrative Studies, 19, 2.

Semushina, L.G., \& laroshenko, N.G. (1990). Soderzhanie i metody obucheniia v SSUZ [The Content and Methods of Training in the Secondary Specialized Education Institutions] (pp. 193). Moscow [in Russian].

Strizhkova, G.M., Astaf'eva, N.E., Filat'eva, L.V., \& lurova, L.L. (2000). Integrirovannyi podkhod pri modelirovanii protsessa lichnostnoorientirovannogo obucheniia v sisteme povysheniia kvalifikatsii [The Integrated Approach for Modeling the Process of StudentCentered Training within the System of the Continuing Professional Development]. Vserossiiskii avgustovskii pedagogicheskii sovet - The All-Russian August Pedagogical Council. Retrieved from: http://pedsovet.alledu.ru [in Russian].

Einstein, A.(1965). Fizika i real'nost' [Physics and Reality] (pp. 111). Moscow: Nauka [in Russian].

Chebyshev, N., \& Kagan, V. (1998). Osnova razvitiia sovremennoi vysshei shkoly [The Basis of Development of the Modern Higher Education]. Vysshee obrazovanie v Rossii - The Higher Education in Russia, 2, 17-22 [in Russian].

Chebyshev, N., \& Kagan, V. (2000). Vysshaia shkola XXI veka: problema kachestva [The Higher Education in the XXI Century: the Problem of Quality]. Vysshee obrazovanie $v$ Rossii - The Higher Education in Russia, 1, $19-27$ [in Russian].

Shestakova, L.A. (2013). Teoreticheskie osnovaniia mezhdistsiplinarnoi integratsii v obrazovatel'nom protsesse vuzov [The Theoretical Foundation of the Interdisciplinary Integration in the Training Process of the Higher Education Institutions]. Vestnik Moskovskogo universiteta imeni S.Iu. Vitte, Series 3: Pedagogika. Psikhologiia. Obrazovatel'nye resursy i tekhnologii - The Bulletin of the Moscow University Named after S.Iu. Witte, Series 3: Pedagogy. Psychology. Educational Resources and Technologies, 1(2), 48 [in Russian].

Shelekhova, L.V. (2014). Mezhdistsiplinarnaia integratsiia kak odno iz effektivnykh napravlenii professional'noi podgotovki studentov ekonomicheskikh spetsial'nostei [The Interdisciplinary Integration as One of the Most Effective Directions of the Professional Training of Students of Economics Specialities]. Trudy mezhdunarodnoi nauchno-prakticheskoi Internet-konferentsii «Prepodavatel' vysshei shkoly v XXI veke» - Proceedings of the International Scientific and Practical Internet-Conference "A Teacher in Higher Education in the XXI Century", Collection 11 (pp. 213-216). Rostov-on-Don: FGBOU VPO RGUPS [in Russian].

Verbitskii, A.A. (1991). Aktivnoe obuchenie v vysshei shkole: kontekstnyi podkhod [Active Training in the Higher Education Institutions: Contextual Approach] (pp. 207). Moscow: Vysshaia Shkola [in Russian]. 